This document is the accepted manuscript version of the following article: Schmid, M. , \& Read, J. (2021). Heat budget of lakes. In Earth systems and environmental sciences. Encyclopedia of inland waters (p. (7 pp.).

https://doi .org/10.1016/B978-0-12-819166-8.00011-6

\title{
Heat budget of lakes
}

\section{Martin Schmid ${ }^{\mathrm{a}}$ and Jordan Read ${ }^{\mathrm{b}}$}

${ }^{a}$ Eawag: Swiss Federal Institute of Aquatic Science and Technology, Kastanienbaum, Switzerland

${ }^{b}$ U.S. Geological Survey, Water Resources Mission Area, Middleton, Wisconsin, U.S.A.

\begin{abstract}
This chapter gives an overview of the heat fluxes between lakes and their environment. The heat budget of most lakes is dominated by heat fluxes at the lake surface, especially shortwave radiation, incoming and outgoing longwave radiation, and the latent heat flux. The seasonality of these fluxes is the most important driver for seasonal mixing processes in lakes. Changes in heat fluxes and the resulting changes in lake thermal structure are the most direct impact of climate change on lakes.
\end{abstract}

\section{Keywords}

shortwave radiation; longwave radiation; latent heat flux; sensible heat flux; climate change

\section{Glossary}

\begin{tabular}{|l|l|}
\hline Albedo & Fraction of incoming shortwave radiation reflected at the lake surface \\
\hline Energy flux & $\begin{array}{l}\text { Rate of energy exchange across an arbitrary or physically meaningful } \\
\text { boundary (e.g., a lake surface) }\end{array}$ \\
\hline $\begin{array}{l}\text { Equilibrium } \\
\text { temperature }\end{array}$ & $\begin{array}{l}\text { Lake surface temperature at which the net lake surface heat flux would } \\
\text { be zero for given meteorological conditions }\end{array}$ \\
\hline Heat flux & A thermal energy flux \\
\hline $\begin{array}{l}\text { Incoming longwave } \\
\text { radiation }\end{array}$ & $\begin{array}{l}\text { Thermal radiation at wavelengths }>3000 \mathrm{~nm} \text { directed from the } \\
\text { atmosphere to the lake surface }\end{array}$ \\
\hline $\begin{array}{l}\text { Incoming shortwave } \\
\text { (solar) radiation }\end{array}$ & $\begin{array}{l}\text { Radiant energy with wavelengths between } ~ 300 \text { and } ~ 3000 \mathrm{~nm}, \\
\text { emitted by the sun and reaching the lake surface after passing through } \\
\text { the atmosphere. }\end{array}$ \\
\hline Lake surface heat fluxes & Heat fluxes between the lake surface and the atmosphere \\
\hline Latent heat flux & $\begin{array}{l}\text { Heat flux between the lake and the atmosphere due to evaporation or } \\
\text { condensation }\end{array}$ \\
\hline $\begin{array}{l}\text { Outgoing longwave } \\
\text { radiation }\end{array}$ & $\begin{array}{l}\text { Thermal radiation at wavelengths }>3000 \text { nm emitted from the lake } \\
\text { surface }\end{array}$ \\
\hline Sensible heat flux & $\begin{array}{l}\text { Heat flux between the lake and the atmosphere due to thermal } \\
\text { conduction }\end{array}$ \\
\hline Surface mixed layer & $\begin{array}{l}\text { Nearly homogeneous water layer extending from the lake surface to a } \\
\text { depth determined by recent turbulent mixing, in classical limnology also } \\
\text { referred to as the epilimnion }\end{array}$ \\
\hline
\end{tabular}




\section{Introduction}

The dynamics of heat fluxes determine lake water temperatures and stratification, which in turn impact water quality and biota. Changes in lake heat budgets are the most direct and primary effect of climate change on lakes, and the monitoring, modelling, and prediction of heat fluxes has a long history in limnology with continued growth in applications for present-day management and understanding of lakes. Due to the importance of heat fluxes to lake ecosystem functions and the need to project the response of lakes to climate change, numerous book chapters (see Wetzel and Likens 2000) and reviews on the topic exist (Henderson-Sellers 1986) as well as tools to support heat flux calculations (Woolway et al. 2015). Here we summarize current knowledge of lake heat fluxes and identify new future research challenges for the field of limnology.

\section{Concepts}

\section{Components of the heat budget}

Short-term temperature changes in lakes are the result of imbalance in heat losses or gains, most of which occur at the lake surface (Figure 1). The timing and magnitude of surface energy fluxes vary in response to atmospheric conditions and the properties of the lake surface. Energy is also lost or gained to the lake below the surface, including from sub-surface inflows, sediment heat exchange, and the attenuation of penetrative radiation within the water column. The heat content of the lake $\left(U_{\text {tot }}\right)$ is defined by the temperature and volume of the water, as well as other water properties that impact water density or specific heat. Any changes to thermal energy are driven by coincident imbalance in energy fluxes $\left(H_{x}\right)$ which are positive when entering the lake:

$$
U_{\text {tot }} / A=H_{S}+H_{A}+H_{W}+H_{E}+H_{C}+H_{F}+H_{D}
$$

Where $A$ is the surface area of the lake. Heat fluxes include downward shortwave $\left(H_{S}\right)$ and longwave $\left(H_{A}\right)$ radiation, outgoing longwave radiation $\left(H_{W}\right)$, latent $\left(H_{E}\right)$ and sensible $\left(H_{C}\right)$ fluxes, advected energy $\left(H_{F}\right)$, and sediment heat flux $\left(H_{D}\right)$.

Accurate measurements of water temperature and volume (used to estimate $U_{\text {tot }}$ ) can be combined with detailed measurements or estimates of energy fluxes $\left(H_{x}\right)$ to define seasonal patterns in lake heat budgets and temperature regimes. As an example, the seasonality of the components of the lake surface heat fluxes for a temperate and a tropical lake are displayed in Figure 2 . The values of missing or uncertain heat flux measurements can be inferred by quantifying the remaining elements of the heat budget and solving for the residuals, such as using temperature and measured energy fluxes to estimate evaporation (Lenters et al. 2005, Winter et al. 2003), or conversely, process-based lake temperature models predict temperatures by including measured or estimated heat fluxes in an energy budget model (Hipsey et al. 2019). A wide range of equations has been used in process-based models to parameterize lake surface heat fluxes. Henderson-Sellers (1986) summarized available parameterizations for all surface heat fluxes, and specific sets of equations can be found, e.g., in Livingstone and Imboden (1989), Fink et al. (2014), Woolway et al. (2015) or Hipsey et al. (2019). 


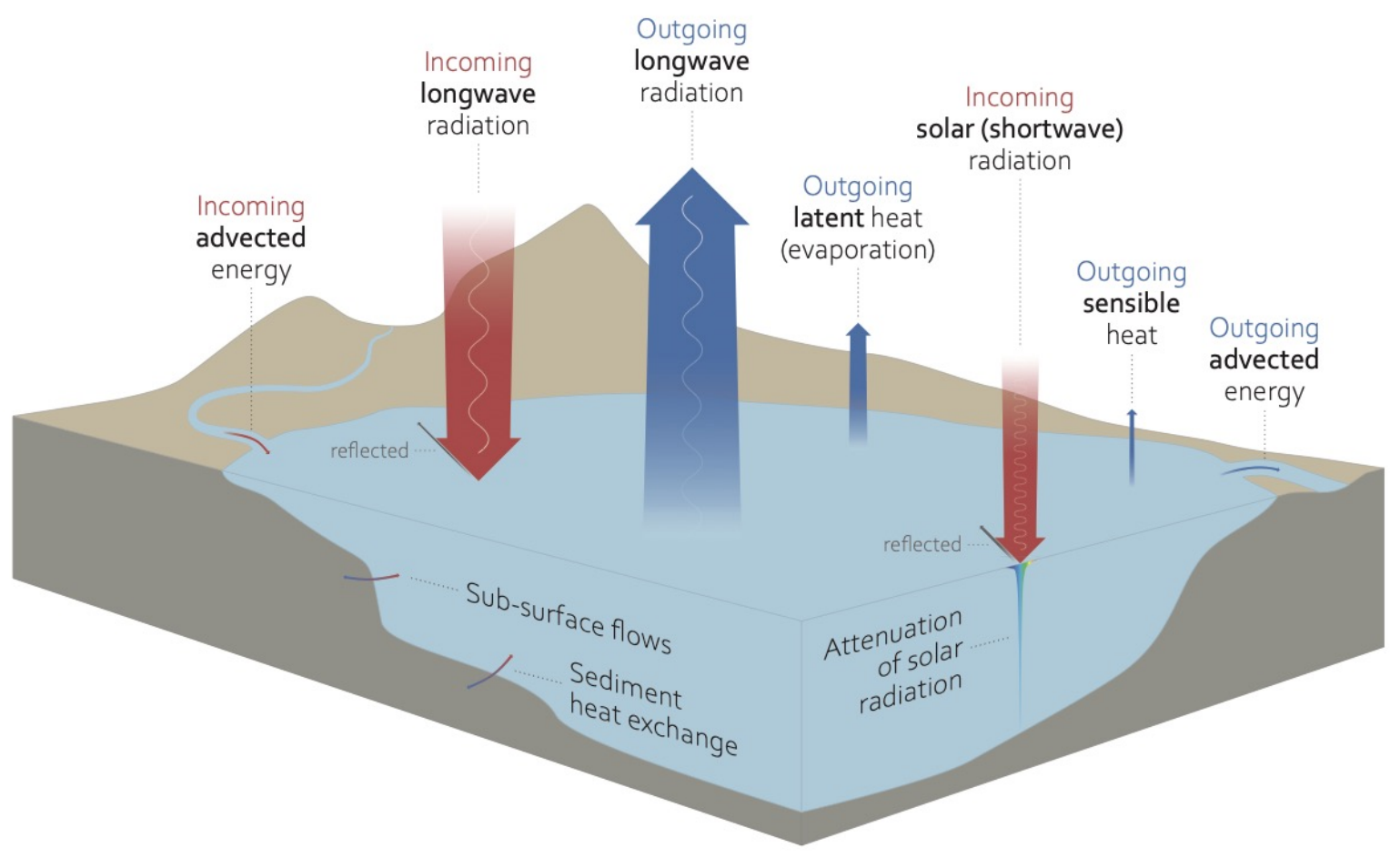

Figure 1. Components of the heat exchange between a lake and the environment.

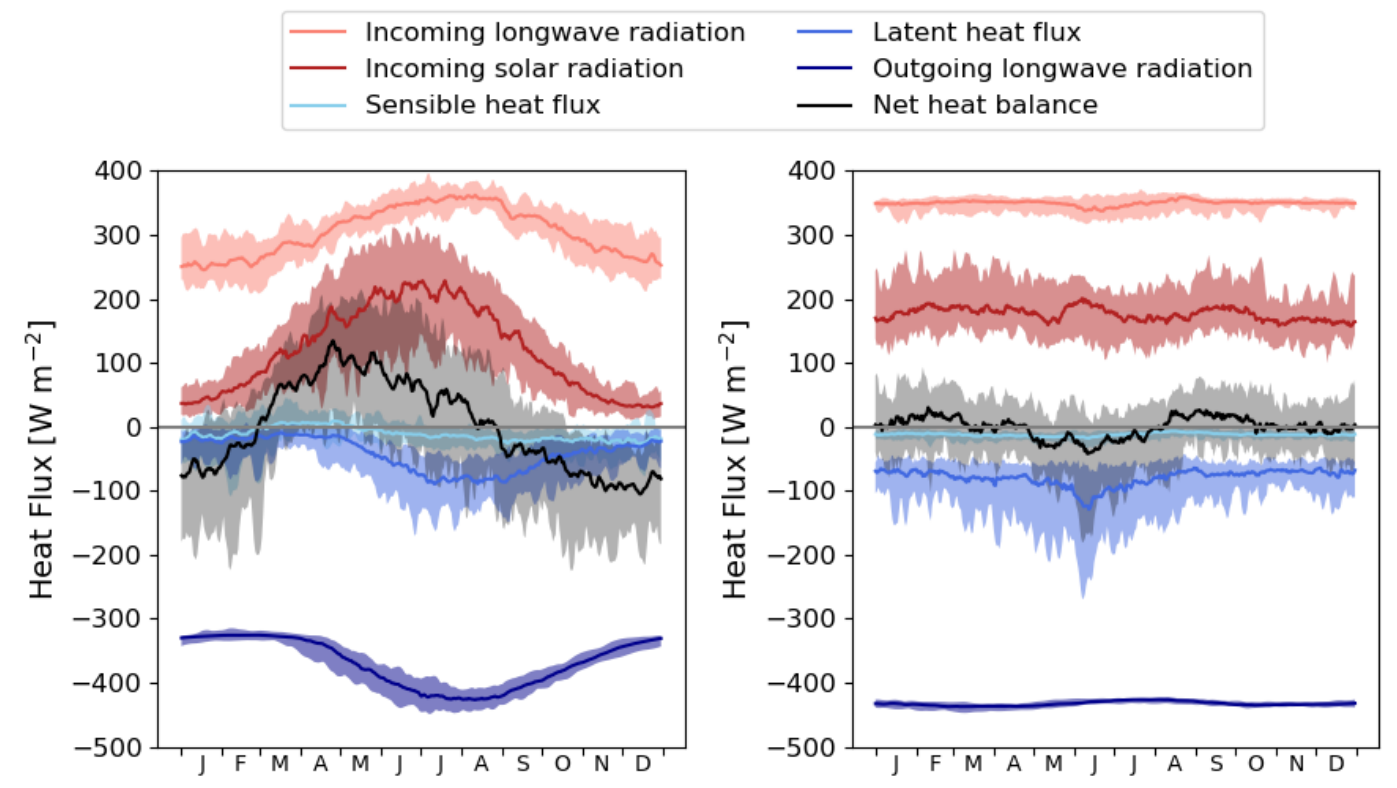

Figure 2: Components of the surface heat fluxes for temperate Lake Zug (Switzerland) and tropical Lake Kivu (DR Congo, Rwanda). The fluxes were calculated with the lake model Simstrat (Goudsmit et al. 2002; Gaudard et al., 2018) based on meteorological data from MeteoSwiss for Lake Zug, and the MiroC5 control scenario from ISIMIP2a for Lake Kivu (F. Bärenbold, pers. comm.). The lines show the median values, the ranges the minima and maxima over a period of 30 years. The data were smoothed with a window of 1 week. The effects of inflows and sediment heat exchange were not included in the calculations. 
Downwelling shortwave radiation $\left(H_{s}\right)$ quantifies the direct energy from the sun as the sum of all wavelengths in the range of $\sim 300-3000 \mathrm{~nm}$ including near-ultraviolet, visible light, and near-infrared radiation. As such, $H_{s}$ varies according to latitude, cloud cover, elevation, and any landscape features that may block the sun's rays from reaching the lake surface (e.g., tall buildings, mountains, and tree canopies). A portion of incoming radiation is reflected by the lake surface, and this loss is defined as the albedo. The shortwave albedo varies according to location (including latitude and elevation), time and day of year, and surface water conditions (e.g., presence of waves or ice cover). Empirical formulations or look-up tables are available for estimating time-varying albedo (Cogley 1979) but it is common to assume a constant value (e.g., Lenters et al. (2005)). After reflection of a fraction of incoming shortwave radiation, shortwave radiation wavelengths beyond the range of visible light are non-penetrative and are treated as a surface energy flux. Radiation of shorter wavelengths penetrates below the surface to be attenuated within the water column or absorbed by the lakebed (Kirk 1994). The percentage of non-penetrative shortwave radiative energy has been defined as ranging from $35 \%$ (Thiery et al. 2014) to $55 \%$ (Hipsey et al. 2019).

\section{Incoming longwave radiation}

Downwelling longwave radiation $\left(H_{A}\right)$ is the radiative energy flux from the atmosphere, and the magnitude of this flux depends primarily on the atmospheric temperature and humidity and cloud cover. See Flerchinger et al. (2009) for various methods to estimate longwave radiation.

Approximately $3 \%$ of downwelling longwave radiation is reflected at the lake's surface (the longwave albedo) and the remaining energy is absorbed by the surface of the lake.

\section{Outgoing longwave radiation}

Longwave radiation is emitted from the lake $\left(H_{w}\right)$ as a function of surface water temperature (in Kelvin) to the fourth power. This outgoing energy flux is typically the largest energy loss term in a lake heat budget, more than offsetting the gains of downwelling $H_{A}$ in most cases (although see section "Overall seasonal heat budget of lakes in different climate zones"). As such, the net sum of incoming and outgoing longwave radiation is often measured near the surface of a lake with paired upward- and downward-oriented sensors, which capture $H_{A}$ and the sum of $H_{W}$ and the portion of $H_{A}$ reflected upward, respectively. When direct measurements are not available, $H_{W}$ is often estimated as $\varepsilon \sigma T_{0}^{4}$ where $\varepsilon$ is the emissivity of water, $\sigma$ is the Stefan-Boltzmann constant, and $T_{0}$ is the absolute temperature of the water surface.

\section{Latent heat flux (evaporation/condensation)}

The flux of latent heat $\left(H_{E}\right)$ at the lake surface quantifies the energy lost or gained to the lake via a state change from liquid water to vapor (evaporation) or vapor to liquid water (condensation). These state changes remove or add water to the lake and are therefore also relevant to the closure of the lake's water budget. Most latent heat exchange occurs as evaporation, where the magnitude of the flux depends on the deficit of vapor in the air and the efficiency of removal, which is based on the atmospheric conditions above the lake. Common methods for estimating the latent heat flux include calculating a residual to the energy budget (Winter et al. 2003), eddy covariance (Nordbo et al. 2011), and mass transfer coefficient parameterization (Rasmussen et al. 1995, Woolway et al. 2015); alternative methods including pan evaporation, mass budget, and use of stable isotopes are also applicable to estimating evaporative water loss. 


\section{Sensible heat flux}

The sensible heat flux $\left(H_{C}\right)$ contrasts with latent heat exchange in that no state change occurs and energy is transferred via conduction between the lake surface and the atmosphere. As with $H_{E}, H_{C}$ can remove or add energy to the lake depending on the prevailing meteorological conditions and the surface temperature of the lake, although most $H_{C}$ fluxes are losses from the lake. The magnitude of the $H_{c}$ flux depends on the difference in temperature between air and water and the atmospheric removal. All primary methods listed above for estimating $H_{E}$ either include a complementary formulation for $H_{C}$ (see Woolway et al. 2015) or involve partitioning the relative contributions of $H_{C}$ and $H_{E}$ as part of the method (in the case of energy budget or eddy covariance methods).

\section{Inflows}

The net heat flux $H_{F}\left(\mathrm{~W} \mathrm{~m}^{-2}\right)$ caused by an inflow with discharge $Q_{\text {in }}$ and temperature $T_{\text {in }}$ is given by Livingstone and Imboden (1989):

$$
H_{F}=\frac{c_{p} \rho}{A} Q_{\text {in }}\left(T_{\text {in }}-T_{\text {out }}\right)
$$

where $c_{p}$ and $\rho$ are the heat capacity and density of water, respectively; and $T_{\text {out }}$ is the outflow temperature, which is close to the lake surface temperature in most lakes. This equation assumes constant lake volume with inflow equal to outflow. For calculating the full heat budget of a lake including volume variations, all individual water fluxes and their temperatures need to be considered (Winter et al. 2003), but in that case care must be taken when comparing components of the heat budget that result from temperature changes with those resulting from volume changes.

If an inflow mixes into the surface mixed layer of a lake, the respective heat flux modifies the lake surface temperature in a similar way as a change in a surface heat flux. As a consequence, the outgoing longwave radiation and the latent and sensitive heat fluxes are modified, partially compensating the heat flux from the inflow. Conversely, if the inflow plunges into the metalimnion, as is typically the case for cold inflows in the warm season, it does not directly affect the lake surface temperature, and the net heat flux from the inflow can accumulate in the lake until the next mixing event. Cool plunging inflows can thus cause a significant cooling of a lake throughout the summer. Similarly, direct groundwater inflows can modify hypolimnion temperatures of a lake (Safaie et al. 2017).

\section{Heat exchange with the sediment}

Heat is generally transported from the water column into the sediment by conduction during the warm season and released back to the water during the cold season (Fang and Stefan 1998), although diurnal heat exchange can also be relevant, especially in shallow lakes or littoral areas where sediments receive direct solar radiation (de la Fuente 2014). The seasonal heat storage in sediments is relevant mainly for the heat budget of shallow lakes, where the seasonal temperature variation above the sediment is large and the heat capacity of the overlying water is comparably small. However, the amount of heat that can be stored and exchanged is limited by the thermal diffusivity of the lake sediment. Even for lakes with large seasonal temperature variation, the seasonal heat flux between the sediment and the overlying water typically does not exceed a few $\mathrm{W}$ $\mathrm{m}^{-2}$. The effects of heat exchange between the sediment and the water are therefore most noticeable in ice-covered lakes where the heat fluxes across the lake surface are limited as well. Heat release from the sediment can be an important driver for both horizontal currents and vertical mixing in ice covered lakes (Kirillin et al. 2012). 
The presence of an ice cover completely modifies the heat fluxes at the lake surface (Leppäranta 2015). The water temperature at the ice-water interface is fixed to $0{ }^{\circ} \mathrm{C}$. The temperature at the surface of the ice cover reacts to meteorological conditions, resulting in a temperature gradient within the ice and a corresponding molecular heat flux. Shortwave radiation can partially penetrate the ice cover and add heat to the underlying lake water. This is particularly important in spring when the ice cover becomes thinner and incoming shortwave radiation increases. The warming of the nearsurface water can then induce convective mixing below the ice cover, as water density increases with temperature at temperatures below $4{ }^{\circ} \mathrm{C}$ (Kirillin et al. 2012). The transfer of shortwave radiation through the ice cover strongly depends on the ice properties and is reduced in the presence of snow.

\section{Anthropogenic heat fluxes}

Heat can be artificially added to or removed from a lake when water is used for cooling or heating purposes. More than $4 \mathrm{GW}$ of heat is introduced globally to freshwater systems from the cooling of power plants. An estimated $44 \%$ of this heat directly enters reservoirs and lakes (Raptis and Pfister 2016) and in some cases causes considerable warming of these waterbodies. One of the best investigated case studies is Lake Stechlin, which was used for cooling a nuclear power plant from 1960 to 1996, with significant effects on its mixing and stratification regime (Kirillin et al. 2013). The remaining $56 \%$ of the heat is introduced into rivers, but can be further transported into downstream lakes (Råman Vinnå et al. 2017). More recently, freshwater systems have been increasingly used for extracting heat for heating purposes, resulting in a cooling of the waterbodies. Heat extraction from deep lakes using heat pumps provides a substantial potential for replacing fossil fuel (Gaudard et al. 2019). Wastewater also typically has different seasonal temperature dynamics than natural surface waters, and its discharge into a lake can therefore modify the heat budget of a lake.

\section{Concept of equilibrium temperature}

The equilibrium lake surface temperature is a useful proxy for the responses of lakes to climate variability and climate change (Schmid et al. 2004). A lake surface equilibrium temperature can be calculated as the temperature for which the net heat flux at the lake surface is zero given a set of meteorological conditions (Edinger et al. 1968). The lake surface temperature tends to exponentially approach this equilibrium temperature if meteorological conditions are held constant. A deviation of the lake surface temperature from the equilibrium temperature of $1^{\circ} \mathrm{C}$ results in a heat flux from the lake of $\sim 30 \mathrm{~W} \mathrm{~m}^{-2}$. This heat flux would be sufficient to cool a water layer of $1 \mathrm{~m}$ thickness by $1^{\circ} \mathrm{C}$ within 1.6 days. Consequently, for constant meteorological conditions, and assuming that the incoming solar radiation is entirely absorbed within the surface mixed layer, the lake surface temperature would exponentially approach the equilibrium temperature with a time scale of 1-2 days for a $1 \mathrm{~m}$ thick mixed layer or 1 month for a $20 \mathrm{~m}$ thick mixed layer. In shallow lakes or in stratified lakes with a shallow surface mixed layer, the lake surface temperature is therefore often close to this equilibrium temperature. For a wide range of meteorological conditions, a change in air temperature of $1^{\circ} \mathrm{C}$ results in a change in lake surface equilibrium temperature of $\sim 0.8^{\circ} \mathrm{C}$ (Schmid et al. 2014). In small and shallow lakes, but also in stratified deeper lakes, a trend in air temperature is therefore expected to result in a corresponding trend in lake surface temperature of $\sim 80 \%$ of the air temperature trend.

\section{Overall seasonal heat budget of lakes in different climate zones}

The importance and seasonality of the different heat fluxes varies with latitude and in different climate zones (e.g., Figure 2). This results in different lake thermal regimes, and also a different sensitivity of lakes in different climate zones to climate change (Maberly et al. 2020). Climatic and 
lake-specific factors (such as morphometry) modulate the seasonal heat budgets in lakes and contribute to global diversity in lake thermal regimes.

In temperate and boreal climate zones, where the majority of lakes are located, the seasonality of the heat budget is mainly driven by the strong seasonality of incoming shortwave and to a lesser extent incoming longwave radiation. As a result, large seasonal amplitudes of lake surface temperatures and dimictic or monomictic mixing regimes are common in these climate zones. The lag between lake temperatures and atmospheric conditions also results in seasonality of outgoing heat fluxes (Livingstone and Imboden 1989), including latent and sensible heat fluxes, which peak in the summer or late fall. Lakes that become cold enough for surface ice to form experience modified heat fluxes and as day length and $H_{s}$ increase in the spring, have a lagged response to warming until ice melts and surface waters return to tighter coupling with atmospheric heat exchanges.

In the tropical climate zone, incoming shortwave radiation is relatively constant throughout the year. Lake surface temperatures vary seasonally only within a few ${ }^{\circ} \mathrm{C}$, and temperature differences between the surface and bottom waters are typically small, resulting in a more dynamic behaviour of the mixed layer depth than in temperate lakes (Lewis Jr. 2000). The lowest lake surface temperatures, and consequently deep mixing events, often occur during the local dry season, when low relative humidity and seasonal winds increase evaporative heat losses and decrease incoming longwave radiation.

\section{Indirect anthropogenic impacts on heat fluxes}

Anthropogenic uses of water and land can result in significant changes to lake heat budgets, which in turn modify lake thermal regimes and ecosystem functions. Tanentzap et al. (2008) examined Clearwater Lake in Canada, where forest regrowth and deacidification (along with coincident changes in water clarity) resulted in lower wind speeds and a colder, more strongly stratified lake. Urban heating impacts on lake heat fluxes can be significant, but few studies exist that describe this phenomenon (although see Cosgrove and Berkelhammer 2018). Using lakes as storage volumes for pumped-storage hydropower can strongly affect their heat budget and thermal properties (Kobler et al. 2018). Other examples of indirect alterations to heat fluxes via anthropogenic change include interventions that modify lake surface area, morphometry, and flowrates via impoundment, channelization, water diversion, and sedimentation. Additionally, agricultural drainage and wastewater effluents have been mostly examined for rivers, but can also affect lake heat budgets (Gaudard et al. 2018). The impact of these anthropogenic alterations on water temperatures depends on their relative magnitude in the overall energy budget of a lake.

\section{Impacts of climate change on heat fluxes and heat budgets}

All heat fluxes mentioned in section "Components of the heat budget" can be modified by climate change. The most direct impact of climate change results from changes in air temperature. Increased air temperature leads to increased incoming longwave radiation and modifies the sensible heat flux between the lake and the atmosphere. For many individual lakes, high correlations between annual or seasonal mean air temperature and lake surface temperature have been observed. At a global scale, for a large number of lakes, the correlation between long-term trends in summer air temperature and lake surface temperature is less consistent (O'Reilly et al. 2015). This observed variability can result from different reactions of different lakes to the forcing, from surface water temperature trends in some lakes being affected by other factors (e.g., trends in clarity), or from the uncertainties in the observed trends of either air or lake surface temperature. Locally, climate change can also lead to modified incoming solar radiation, relative humidity, average wind speeds, and the timing and magnitude of hydrologic fluxes, with corresponding impacts on lake heat fluxes. For example, reduced wind speeds have been proposed to have accelerated warming of lakes in the 
Northern Hemisphere (Woolway et al. 2019). For boreal and temperate lakes, climate change typically results in a prolongation of the summer stratified period with a significant additional accumulation of heat throughout the summer, which then needs to be removed again in autumn before complete lake mixing can occur.

\section{Conclusions / Synthesis}

The heat fluxes between lakes and the environment determine the dynamics of their thermal structure, and in consequence, are a control on biogeochemical processes in lakes. The heat budget of an individual lake depends on the local climatic conditions and is modulated by the lake's properties. While incoming shortwave and longwave and outgoing longwave radiation contribute most to the heat budget, other heat fluxes can nevertheless be relevant for driving seasonality, e.g the latent heat flux in tropical lakes. Modification of the heat fluxes, and in consequence of the thermal structure, is the most direct impact of climate change on lakes. The heat budget of lakes can otherwise be affected by anthropogenic activities, either directly by heat discharge or extraction, or indirectly by changes in a lake's watershed.

\section{Knowledge gaps}

- The spatial heterogeneity in lake thermal properties, fluxes, and in-lake responses to forcings (e.g., evaporative cooling, locations of warm water inflows, and complex wind fields) may be relevant but has rarely been investigated.

- Direct measurements of heat fluxes (e.g., eddy covariance for sensible and latent heat) are rare.

- The representation of heat fluxes in numerical lake models is often simplistic and constrained by measurement limitations (e.g., single point weather observations).

- Data for calculating fluxes is biased to temperate regions, and few studies have taken place at high altitude or in tropical lakes.

- Studies quantifying the effects of diffuse anthropogenic heat sources (e.g., urbanization, land use change) on lake temperatures are rare.

\section{Case studies}

\begin{tabular}{|l|l|l|l|l|}
\hline Lake & Country & Coordinates & Main Topic & Key Reference \\
\hline Lake Valkea-Kotinen & Finland & $61^{\circ} 14^{\prime} \mathrm{N} / 25^{\circ} 03^{\prime} \mathrm{E}$ & $\begin{array}{l}\text { Measurements of heat } \\
\text { fluxes over a boreal lake }\end{array}$ & Nordbo et al. (2011) \\
\hline Lake Stechlin & Germany & $53^{\circ} 09^{\prime} \mathrm{N} / 13^{\circ} 01^{\prime} \mathrm{E}$ & $\begin{array}{l}\text { Impact of thermal } \\
\text { discharge }\end{array}$ & Kirillin et al. (2013) \\
\hline Lake Constance & $\begin{array}{l}\text { Germany, } \\
\text { Switzerland }\end{array}$ & $47^{\circ} 35^{\prime} \mathrm{N} / 09^{\circ} 28^{\prime} \mathrm{E}$ & $\begin{array}{l}\text { Climate change effects on } \\
\text { heat fluxes }\end{array}$ & Fink et al. (2014) \\
\hline Lower Lake Zurich & Switzerland & $47^{\circ} 15^{\prime} \mathrm{N} / 08^{\circ} 40^{\prime} \mathrm{E}$ & $\begin{array}{l}\text { Contributions of forcing } \\
\text { factors to recent warming }\end{array}$ & $\begin{array}{l}\text { Schmid and Köster } \\
\text { (2016) }\end{array}$ \\
\hline Tub Lake & Wisconsin, USA & $45^{\circ} 16^{\prime} \mathrm{N} / 91^{\circ} 27^{\prime} \mathrm{W}$ & $\begin{array}{l}\text { Sediment heat budget for } \\
\text { small temperate lakes }\end{array}$ & $\begin{array}{l}\text { Likens and Johnson } \\
(1969)\end{array}$ \\
\hline Mirror Lake & $\begin{array}{l}\text { New Hampshire, } \\
\text { USA }\end{array}$ & $43^{\circ} 56^{\prime} \mathrm{N} / 71^{\circ} 41^{\prime} \mathrm{W}$ & $\begin{array}{l}\text { Energy budget method to } \\
\text { estimate evaporation }\end{array}$ & Winter et al. (2003) \\
\hline Lake Taihu & China & $31^{\circ} 25^{\prime} \mathrm{N} / 120^{\circ} 13^{\prime} \mathrm{E}$ & $\begin{array}{l}\text { Factors driving evaporation } \\
\text { in a subtropical lake }\end{array}$ & Xiao et al. (2020) \\
\hline Nam Co & China & $30^{\circ} 42^{\prime} \mathrm{N} / 90^{\circ} 33^{\prime} \mathrm{E}$ & Heat fluxes at high altitudes & Wang et al. (2015) \\
\hline Lake Kivu & DR Congo, Rwanda & $02^{\circ} 00^{\prime} \mathrm{S} / 29^{\circ} 00^{\prime} \mathrm{E}$ & $\begin{array}{l}\text { Effect of rainfall on lake } \\
\text { surface temperature }\end{array}$ & Rooney et al. (2018) \\
\hline Lake Tanganyika & $\begin{array}{l}\text { Burundi, DR Congo, } \\
\text { Tanzania, Zambia }\end{array}$ & $06^{\circ} 30^{\prime} \mathrm{S} / 29^{\circ} 50^{\prime} \mathrm{E}$ & $\begin{array}{l}\text { Sensible and latent heat } \\
\text { fluxes }\end{array}$ & $\begin{array}{l}\text { Verburg and } \\
\text { Antenucci (2010) }\end{array}$ \\
\hline
\end{tabular}




\section{References}

Cogley, J.G. (1979) The albedo of water as a function of latitude. Monthly Weather Review 107, 775781.

Cosgrove, A. and Berkelhammer, M. (2018) Downwind footprint of an urban heat island on air and lake temperatures. npj Climate and Atmospheric Science 1(1), 46.

de la Fuente, A. (2014) Heat and dissolved oxygen exchanges between the sediment and water column in a shallow salty lagoon. Journal of Geophysical Research: Biogeosciences 119(4), 596-613.

Edinger, J.E., Duttweiler, D.W. and Geyer, J.C. (1968) The response of water temperatures to meteorological conditions. Water Resources Research 4, 1137-1143.

Fang, X. and Stefan, H.G. (1998) Temperature variability in lake sediments. Water Resources Research 34(4), 717-729.

Fink, G., Schmid, M., Wahl, B., Wolf, T. and Wüest, A. (2014) Heat flux modifications related to climate-induced warming of large European lakes. Water Resources Research 50, 2072-2085.

Flerchinger, G.N., Xaio, W., Marks, D., Sauer, T.J. and Yu, Q. (2009) Comparison of algorithms for incoming atmospheric long-wave radiation. Water Resources Research 45, W03423.

Gaudard, A., Weber, C., Alexander, T.J., Hunziker, S. and Schmid, M. (2018) Impacts of using lakes and rivers for extraction and disposal of heat. Wiley Interdisciplinary Reviews: Water 5(5), e1295.

Gaudard, A., Råman Vinnå, L., Bärenbold, F., Schmid, M., Bouffard, D. (2019). Toward an open-access of high-frequency lake modelling and statistics data for scientists and practitioners. The case of Swiss Lakes using Simstrat v2.1. Geoscientific Model Development 12: 3955-3974

Gaudard, A., Wüest, A. and Schmid, M. (2019) Using lakes and rivers for extraction and disposal of heat: estimate of regional potentials. Renewable Energy 134, 330-342.

Goudsmit, G.-H., Burchard, H., Peeters, F., Wüest, A., 2002. Application of k- $\epsilon$ turbulence models to enclosed basins: The role of internal seiches. J. Geophys. Res. Oceans 107, 3220.

Henderson-Sellers, B. (1986) Calculating the surface energy balance for lake and reservoir modeling: a review. Reviews of Geophysics 24(3), 625-649.

Hipsey, M.R., Bruce, L.C., Boon, C., Busch, B., Carey, C.C., Hamilton, D.P., Hanson, P.C., Read, J.S., de Sousa, E., Weber, M. and Winslow, L.A. (2019) A General Lake Model (GLM 3.0) for linking with high-frequency sensor data from the Global Lake Ecological Observatory Network (GLEON). Geosci. Model Dev. 12(1), 473-523.

Kirillin, G., Leppäranta, M., Terzhevik, A., Granin, N., Bernhardt, J., Engelhardt, C., Efremova, T., Golosov, S., Palshin, N., Sherstyankin, P., Zdorovennova, G. and Zdorovennov, R. (2012) Physics of seasonally ice-covered lakes. Aquatic Sciences 74, 659-682.

Kirillin, G., Shatwell, T. and Kasprzak, P. (2013) Consequences of thermal pollution from a nuclear plant on lake temperature and mixing regime. Journal of Hydrology 496, 47-56.

Kirk, J.T.O. (1994) Light and Photosynthesis in Aquatic Ecosystems, Cambridge University Press, Cambridge.

Kobler, U.G., Wüest, A. and Schmid, M. (2018) Effects of lake-reservoir pumped-storage operations on temperature and water quality. Sustainability 10(6), 1968.

Lenters, J.D., Kratz, T.K. and Bowser, C.J. (2005) Effects of climate variability on lake evaporation: Results from a long-term energy budget study of Sparkling Lake, northern Wisconsin (USA). Journal of Hydrology 308(1), 168-195.

Leppäranta, M. (2015) Freezing of lakes and the evolution of their ice cover, Springer, Heidelberg.

Lewis Jr., W.M. (2000) Basis for the protection and management of tropical lakes. Lakes and Reservoirs: Research and Management 5, 35-48.

Likens, G.E. and Johnson, N.M. (1969) Measurement and analysis of the annual heat budget for the sediments in two Wisconsin lakes. Limnology and Oceanography 14(1), 115-135.

Livingstone, D.M. and Imboden, D.M. (1989) Annual heat balance and equilibrium temperature of Lake Aegeri, Switzerland. Aquatic Sciences 51, 351-369. 
Maberly, S.C., O'Donnell, R.A., Woolway, R.I., Cutler, M.E.J., Gong, M., Jones, I.D., Merchant, C.J., Miller, C.A., Politi, E., Scott, E.M., Thackeray, S.J. and Tyler, A.N. (2020) Global lake thermal regions shift under climate change. Nature Communications 11, 1232.

Nordbo, A., Launiainen, S., Mammarella, I., Leppäranta, M., Huotari, J., Ojala, A. and Vesala, T. (2011) Long-term energy flux measurements and energy balance over a small boreal lake using eddy covariance technique. Journal of Geophysical Research: Atmospheres 116(D2).

O'Reilly, C.M., Sharma, S., Gray, D.K., Hampton, S.E., Read, J.S., Rowley, R.J., Schneider, P., Lenters, J.D., McIntyre, P.B., Kraemer, B.M., Weyhenmeyer, G.A., Straile, D., Dong, B., Adrian, R., Allan, M.G., Anneville, O., Arvola, L., Austin, J., Bailey, J.L., Baron, J.S., Brookes, J.D., de Eyto, E., Dokulil, M.T., Hamilton, D.P., Havens, K., Hetherington, A.L., Higgins, S.N., Hook, S., Izmest'eva, L.R., Jöhnk, K., Kangur, K., Kasprzak, P., Kumagai, M., Kuusisto, E., Leshkevich, G., Livingstone, D.M., MacIntyre, S., May, L., Melack, J.M., Müller-Navarra, D.C., Naumenko, M., Nõges, P., Nõges, T., North, R.P., Plisnier, P.D., Rigosi, A., Rimmer, A., Rogora, M., Rudstam, L.G., Rusak, J.A., Salmaso, N., Samal, N.R., Schindler, D.E., Schladow, G., Schmid, M., Schmidt, S.R., Silow, E., Soylu, M.E., Teubner, K., Verburg, P., Voutilainen, A., Watkinson, A., Williamson, C.E. and Zhang, G. (2015) Rapid and highly variable warming of lake surface waters around the globe. Geophysical Research Letters 42, 10773-10781.

Råman Vinnå, L., Wüest, A. and Bouffard, D. (2017) Physical effects of thermal pollution in lakes. Water Resources Research 53, 3968-3987.

Raptis, C.E. and Pfister, S. (2016) Global freshwater thermal emissions from steam-electric power plants with once-through cooling systems. Energy 97, 46-57.

Rasmussen, A.H., Hondzo, M. and Stefan, H.G. (1995) A test of several evaporation equations for water temperature simulations in lakes. JAWRA Journal of the American Water Resources Association 31(6), 1023-1028.

Rooney, G.G., Van Lipzig, N. and Thiery, W. (2018) Estimating the effect of rainfall on the surface temperature of a tropical lake. Hydrology and Earth System Sciences 22, 6357-6369.

Safaie, A., Litchman, E. and Phanikumar, M.S. (2017) Evaluating the role of groundwater in circulation and thermal structure within a deep inland lake. Advances in Water Resources 108, 310-327.

Schmid, M., Hunziker, S. and Wüest, A. (2014) Lake surface temperatures in a changing climate: a global sensitivity analysis. Climatic Change 124, 301-315.

Schmid, M. and Köster, O. (2016) Excess warming of a Central European lake driven by solar brightening. Water Resources Research 52, 8103-8116.

Tanentzap, A.J., Yan, N.D., Keller, B., Girard, R., Heneberry, J., Gunn, J.M., Hamilton, D.P. and Taylor, P.A. (2008) Cooling lakes while the world warms: Effects of forest regrowth and increased dissolved organic matter on the thermal regime of a temperate, urban lake. Limnology and Oceanography 53(1), 404-410.

Thiery, W., Martynov, A., Darchambeau, F., Descy, J.P., Plisnier, P.D., Sushama, L. and van Lipzig, N.P.M. (2014) Understanding the performance of the FLake model over two African Great Lakes. Geoscientific Model Development 7(1), 317-337.

Verburg, P. and Antenucci, J.P. (2010) Persistent unstable atmospheric boundary layer enhances sensible and latent heat loss in a tropical great lake: Lake Tanganyika. Journal of Geophysical Research: Atmospheres 115(D11).

Wang, B., Ma, Y., Chen, X., Ma, W., Su, Z. and Menenti, M. (2015) Observation and simulation of lakeair heat and water transfer processes in a high-altitude shallow lake on the Tibetan Plateau. Journal of Geophysical Research: Atmospheres 120(24), 12327-12344.

Wetzel R.G., Likens G.E. (2000) The Heat Budget of Lakes. In: Limnological Analyses. Springer, New York, NY

Winter, T.C., Buso, D.C., Rosenberry, D.O., Likens, G.E., Sturrock, A.J.M. and Mau, D.P. (2003) Evaporation determined by the energy-budget method for Mirror Lake, New Hampshire. Limnology and Oceanography 48(3), 995-1009.

Woolway, R.I., Jones, I.D., Hamilton, D.P., Maberly, S.C., Muraoka, K., Read, J.S., Smyth, R.L. and Winslow, L.A. (2015) Automated calculation of surface energy fluxes with high-frequency lake buoy data. Environmental Modelling \& Software 70, 191-198. 
Woolway, R.I., Merchant, C.J., Van Den Hoek, J., Azorin-Molina, C., Nõges, P., Laas, A., Mackay, E.B. and Jones, I.D. (2019) Northern Hemisphere atmospheric stilling accelerates lake thermal responses to a warming world. Geophysical Research Letters 46, 11983-11992.

Xiao, W., Zhang, Z., Wang, W., Zhang, M., Liu, Q., Hu, Y., Huang, W., Liu, S. and Lee, X. (2020) Radiation Controls the Interannual Variability of Evaporation of a Subtropical Lake. Journal of Geophysical Research: Atmospheres 125(8), e2019JD031264.

\section{Further reading}

Bengtsson L. (2012) Thermal Regime of Lakes. In: Bengtsson L., Herschy R.W., Fairbridge R.W. (eds) Encyclopedia of Lakes and Reservoirs. Encyclopedia of Earth Sciences Series. Springer, Dordrecht

Henderson-Sellers, B. (1986) Calculating the surface energy balance for lake and reservoir modeling: a review. Reviews of Geophysics 24(3), 625-649.

Imberger, J. and Patterson, J.C. (1990) Physical Limnology. Advances in applied mechanics 27, 303475.

Imboden, D. and Wüest, A. (1995) Physics and chemistry of lakes. Lerman, A., Imboden, D. and Gat, J. (eds), pp. 83-138, Springer, Berlin.

Leppäranta, M. (2015) Freezing of lakes and the evolution of their ice cover, Springer, Heidelberg.

Wetzel R.G., Likens G.E. (2000) The Heat Budget of Lakes. In: Limnological Analyses. Springer, New York, NY

\section{Relevant Websites}

- Great Lakes Operational Forecast System (GLOFS), includes calculated surface heat fluxes for the Laurentian Great Lakes: https://www.glerl.noaa.gov/res/glcfs-fvcom/ncast.php

- Lake Heat Flux Analyzer (Woolway et al., 2015), a Matlab code package for calculating heat fluxes for lakes: https://github.com/GLEON/HeatFluxAnalyzer

- Copernicus Global Land Service (CGLOPS) - lake surface temperatures from remote sensing : https://land.copernicus.eu/global/products/lswt

- Output of Inter-Sectoral Impact Model Intercomparison Project, including simulated lake surface heat fluxes by several lake models for a number of climate scenarios: https://esg.pikpotsdam.de/search/isimip/

Any use of trade, firm, or product names is for descriptive purposes only and does not imply endorsement by the U.S. Government 